\title{
Chapter 3 \\ Income Inequality and Residential Segregation in European Cities
}

\author{
Tiit Tammaru, Anastasia Sinitsyna, Alireza Akhavizadegan, \\ Maarten van Ham, Szymon Marcińczak, and Sako Musterd
}

\begin{abstract}
Based on extensive research with distinguished scholars within the book project 'Socioeconomic Segregation in European Capital Cities', this chapter summarizes the key trends in income inequality and socioeconomic segregation in Europe. We draw our data from the two last census rounds, and we focus on the most common indicators of income inequality (Gini Index) and residential segregation (Dissimilarity Index). We find that levels of residential segregation grew between the two last censuses in most of the cities included in our study. Changes in residential segregation follow changes in income inequality with a time lag, and it tends to happen in both directions. Low levels of income inequality relate to low levels of segregation after 10 years, and high levels of inequality relate to high levels of segregation after 10 years.
\end{abstract}

Keywords Income inequality $\cdot$ Residential segregation $\cdot$ Comparative urban studies $\cdot$ Europe

T. Tammaru (凶) $\cdot$ A. Sinitsyna $\cdot$ A. Akhavizadegan Human Geography, University of Tartu, Tartu, Estonia e-mail: tiit.tammaru@ut.ee

A. Sinitsyna

e-mail: anastasia.sinitsyna@ut.ee

A. Akhavizadegan

e-mail: aakhv110@gmail.com

M. van Ham

Department of Urbanism, Delft University of Technology, Delft, Netherlands

e-mail: m.vanham@tudelft.nl

S. Marcińczak

Faculty of Geography, University of Łódź, Lodz, Poland

e-mail: szymon.marcinzak@geo.uni.lodz.pl

S. Musterd

Department of Geography, Planning and International Development Studies, University of Amsterdam, Amsterdam, Netherlands

e-mail: s.musterd@uva.nl 


\subsection{Introduction}

Income inequality has long been a feature of most societies and segregation has long been a feature of cities (Nightingale 2012; Tammaru et al. 2020). Very high levels of income inequality and high levels of residential segregation are also important policy concerns since they may bring negative consequences for cities and people, ranging from a lack of opportunities, constraints on social mobility, poverty, the intergenerational transmission of disadvantage and even social unrest (Galster et al. 2015; van Ham et al. 2018). Vulnerable population groups, such as low-income households and ethnic minorities, tend to concentrate in the poorest neighbourhoods in the case of modest public interventions, for example through various interventions that stem from social policy and housing policy (Scarpa 2016). The higher the level of income inequality, the more difficult it is for people with low incomes and their children to fully realise their abilities and skills, and to undertake upward social mobility (Krueger 2012) and upward residential mobility (Nieuwenhuis et al. 2020).

Although the exact mechanisms that link inequality and segregation may be complex (Fujita and Maloutas 2016; Tammaru et al. 2020; Musterd 2020); there seems to be a regularity that societies with high levels of inequality may become less dynamic with petrified class structures as the fortunes of children depend heavily on the fortunes of their parents (Arundel 2017; Hochstenbach and Boterman 2017; Nieuwenhuis et al. 2020). Low income and spatial clustering of vulnerable population groups may lead to the vicious circle of segregation, also across generations, as social and spatial disadvantage is passed from parents to children (van Ham et al. 2018). High levels of residential segregation between socioeconomic groups tend to be related to liberal societies (Tammaru et al. 2016a, b).

The vicious circle of segregation may evolve, operating as follows. Money buys choice on the housing market and it tends to sort people with different incomes to different neighbourhoods (Hulchansky 2010). Living in certain neighbourhoods may limit job opportunities, as claimed by the spatial mismatch hypothesis (Kain 1968). According to neighbourhood effects research, living in certain neighbourhoods affects many other individual outcomes, ranging from the labour market to health (Johnston et al. 2005; Wilson 1987). Neighbourhood effects may run also across generations (Hedman and van Ham 2021). For example, when schools are neighbourhood based, sorting of parents into certain houses and neighbourhoods shapes the sorting of children into schools (Boterman et al. 2019). Schools are places where children get both academic and non-academic knowledge, where values form and friends are made. Evidence shows that schools located in high-income neighbourhoods tend to have better academic achievements than in those of low-income neighbourhoods (Owens and Candipan 2019). The differences that evolve at schools tend to lead to differences in labour market outcomes that, in turn, shape housing choice.

High levels of inequality may cause social problems. However, aiming to eliminate inequality may also be detrimental to individual lives. Post-World War II experiments in centrally planned European countries did lead to high levels of equality as well as 
to low levels of segregation (Tammaru et al. 2016a, b). These experiments revealed the disadvantages of socially flat and residentially mixed societies. For example, cities became less dynamic, less diverse and dull places to live in (Szelenyi 1996). Hence, widespread public interventions in all domains of society can reduce income inequality and residential segregation but can also result in low levels of motivation to achieve. Consequently, the economy can lack dynamism, leading to sluggish growth and low productivity (Kornai 1992). Hence, it seems that both extreme levels of inequality and extreme levels of equality may have negative consequences on individuals, cities and societies.

The current chapter aims to provide an overview of trends in socio-economic residential segregation in European cities and to investigate the extent to which these trends are related to different levels of income inequality. The chapter draws on earlier work by Tammaru et al. (2016a, b) based on the cities of Amsterdam, Athens, Budapest, Helsinki, London, Madrid, Milan, Oslo, Prague, Riga, Tallinn, Stockholm and Vilnius. We have also included Helsinki in our analysis.

The chapter is structured as follows. The first section reviews the literature on the interplay between income inequality and segregation. This is followed by a section on data and methods. The study employs data on income inequality from the years 1990, 2000 and 2010, and data on residential segregation from 2000 and 2010 in order to account for possible lagged effects between changes in the two variables. We then present the main findings. We start our analysis with a discussion of income inequality based on the Gini Index. We then proceed with the analysis of segregation in form of the Dissimilarity Index by measuring the difference in the distribution of top and bottom socioeconomic groups across urban neighbourhoods. The chapter ends with an analysis that explores the link between income inequality and segregation by lagging the Gini Index 10 years (being measured in 1990, 2000) compared to the Dissimilarity Index (measured in 2000 and 2010). We do not focus on the potential reverse relationship: i.e. the potential for segregation to cause income inequality to increase (Cutler and Glaeser 1997).

\subsubsection{Link Between Income Inequality and Residential Segregation}

The focus of this chapter is on the link between income inequality and residential segregation between the top and bottom socioeconomic groups. There are several mechanisms that connect income inequality and residential segregation (Tammaru et al. 2020):

(1) changes in household numbers that affect the distribution of top and bottom socioeconomic groups over neighbourhoods (population shrinkage or growth, natural change, immigration); 
(2) the geography of housing and its differentiation, attracting, forcing or constraining the residential mobility of households earning different incomes, and

(3) residential mobility of top and bottom socioeconomic groups within urban regions (people change residential neighbourhoods because their incomes increase or decrease).

\section{Changes in the Distribution of High-and Low-Income Occupations}

Since the seminal work by Sassen (1991), debates on changing labour markets, and how they are affected by globalisation and migration, revolve around issues of social polarisation and professionalization (Hamnett 2020; van Ham et al. 2020). According to Sassen (1991), globalisation is the driving force for social polarisation. Highly skilled professionals, especially in advanced business services and in the technology sector, are able to sell their labour globally to large multi-national companies. Countries, cities and companies compete for talent, pushing up their wages. Knowledgeintensive systems and technological advancements have become complementary tools for performing tasks for highly skilled professionals, contributing to an increase in their productivity (Autor et al. 2001; Cirillo 2017). Low skilled workers in developed countries compete with workers in developing countries, which limits their wage growth. Professionalisation implies that, over time, a trend for strong upward mobility across the available workforce can take place alongside an overall improvement of education in each subsequent generation (Hamnett 1994). Hence, even if some polarization takes place, it is a secondary process, while professionalization or overall upward occupational and income mobility is the main trend (Hamnett 2020; van Ham et al. 2020).

\section{The Geography of Housing}

Residential segregation is structured by the availability of different types of housing in different parts of a city. When different types of housing (by tenure and price) are located in particular types of neighbourhood, the result will be residential segregation by income (Tammaru et al. 2016a, b; Musterd et al. 2017). School segregation is strongly related to residential segregation, for a recent overview, see Boterman et al. (2019). Labour market segregation is related to skills and education and so, over time, an inter-generational vicious circle of segregation may start to operate, leading to an overlap between social and spatial disadvantage (van Ham et al. 2018). Housing forms one of the key elements in this spiral of segregation since housing is often the most expensive 'good' that people buy in their lifetime. Money buys choice on the housing market, but housing choice also determines location, schooling and opportunities. As young people increasingly rely on their parents for help in entering the housing market, there is an inter-generational dimension not only in educational and labour market disadvantage but also in housing market disadvantage (Hochstenbach and Musterd 2018). 


\section{Residential Mobility of High- and Low-Income Families}

Residential sorting hinges also on residential preferences that may both contribute to higher levels of residential segregation, or to temporarily lower levels of segregation. Two spatial mega-trends seem to have started within European cities: one related to the gentrification of the rich and the other to the suburbanisation of the poor (Hochstenbach and Musterd 2018; van Ham et al. 2020). As a consequence of these trends, we generally see growing levels of segregation between the rich and poor both in European cities (Tammaru et al. 2016a, b) as well as elsewhere in the world (van Ham et al. 2020; Musterd 2020). House values have risen quickly in attractive inner-city neighbourhoods so that such housing in these areas is beyond the reach of most urban residents. However, the relationship between inequality and socio-economic segregation is characterised by a time lag (Marcińczak et al. 2016). Likewise resorting to high- and low-income households across neighbourhoods-e.g. at times of gentrification-can cause temporary mixing of income groups, lowering rather than increasing levels of segregation (Musterd and van Gent 2016; Tammaru et al. 2016a, b). As a result of time lags and mixing, it may take even several decades before a rise in income inequality starts to contribute to the rise of residential segregation (Wessel 2016).

\subsection{Data and Methods}

The data sample for this chapter derives from the edited book project 'SocioEconomic Segregation in European Cities: East Meets West' (Tammaru et al. 2016a, b). We are very grateful to all the researchers that participated in this book project, and the help we received in solving the various challenges of achieving a comparative dataset. First, we had two different variables for measuring socio-economic status, occupation and income. Where census data were available, we had to rely on occupation (Athens, Budapest, Madrid, Milan, London, Prague, Riga). In countries that use register data, we relied on income (Amsterdam, Oslo, Helsinki and Stockholm) and we compare people who belong to the first- and fifth-income quintile in calculating the Dissimilarity Index. In all other cities, census data on occupations are used. We used the International Standard Classification of Occupations (ISCO) to define the main occupational groups. These are managers, senior officials and legislators; professionals; technicians and associate professionals; clerks; service and sales workers; craft and related trades workers; plant and machine operators, and assemblers; and elementary occupations. We compare managers and elementary occupations in calculating the Dissimilarity Index. Occupation and income are obviously not the same concepts but they are related and, as a rule of thumb, the higher the job in the occupational ladder the higher the income (Tammaru et al. 2016a, b).

The study is based on data from the 2000 and 2010 census rounds. Cities are defined as a common housing market with a continuous built-up area. We calculated the Dissimilarity Index between the top and bottom occupational/income groups at 
both census dates. We then contrasted the values of the Dissimilarity Index with the national level Gini Index since Gini Index values are not available for us at the city level. As a rule of thumb, inequalities in large cities tend to be higher than national averages, which implies that in using country-level estimates, we underestimate levels of inequality of the cities in our study.

Our main interest lies in the relationship between changes in the Gini Index and changes in the Dissimilarity Index. We measured the Gini Index 10 years earlier than the Dissimilarity Index since transmission of changes in income inequality to changes in residential segregation are likely to take some time (Tammaru et al. 2020). We explored the relationship between city-level Dissimilarity Index values in 2000 and Gini Index levels in 1990, and the relationship between city-level Dissimilarity Index values in 2010 and Gini Index levels in 2000. As Eurostat does not provide historical Gini Index estimates, we relied on harmonised Gini Index values produced by Tóth (2013). We should be aware of the different starting positions for cities in Eastern Europe and across the rest of Europe. The year 1990 is especially relevant in this respect as it is statistically less than 1 year before or after regime changes in various Eastern European countries. Processes of inequality change had already been operating across the rest of Europe for some time before this. We should also bear in mind that the changes that took place in the built environment and segregation were significantly slower than those which took place within economic structures and income inequality in Eastern Europe in the 1990s (Marcińczak et al. 2015). We consequently assume that levels of residential segregation in Eastern Europe were still low in 2000, reflecting the patterns inherited from the period of central planning. However, due to the growth of inequality in the 1990s in Eastern Europe, we expected to see a significant increase in levels of residential segregation by 2010 . In other words, we expected to find a similarly strong relationship between levels of lagged income inequality measured in 2000 and levels of residential segregation measured in 2010 .

\subsection{Findings: Income Inequality and Residential Segregation in Europe}

\subsubsection{Changes in the Level of Income Inequality}

The value of the Gini Index measuring income inequality is higher than 35 in most world countries. Within Europe, however, Gini Index values tend to be lower than 35 . In 1990, there was a clear geographic pattern in Gini Index values, with the lowest values in Northern and Eastern Europe, and the highest in Southern and Western Europe (Fig. 3.1). We can also observe that income inequalities grew across Europe in the 1990s or immediately after the Fall of the Berlin Wall and the demise of the Soviet Union (Vihalemm et al. 2017). However, the growth in inequality varies considerably from country to country, and it is important to distinguish between 


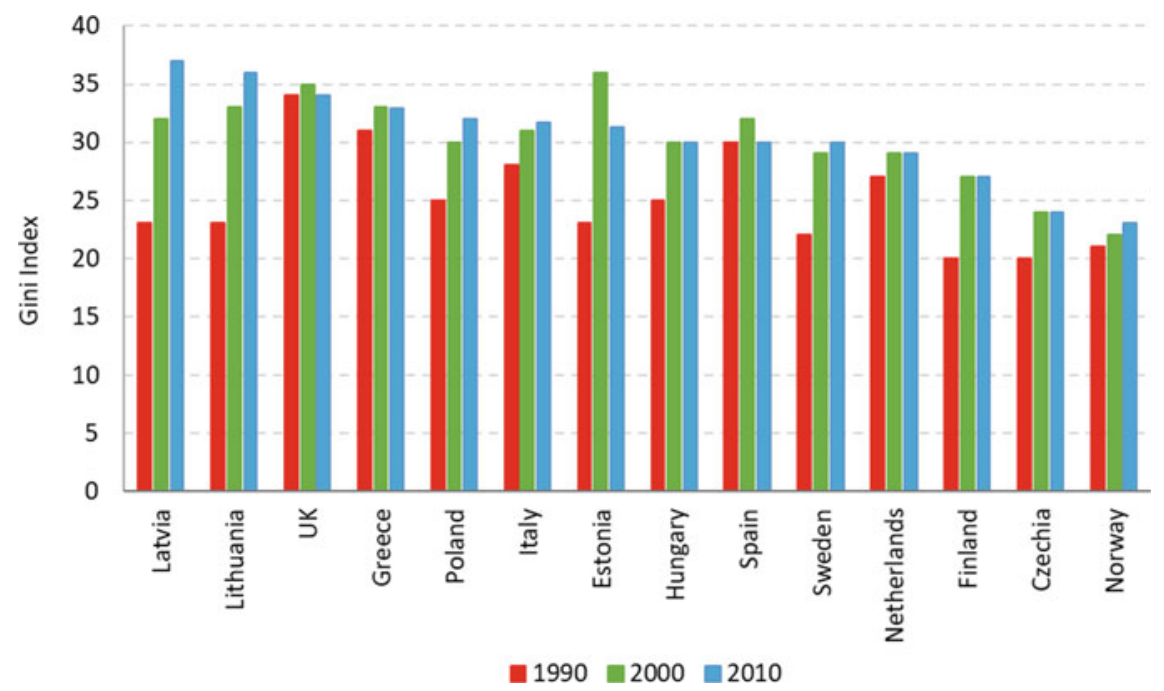

Fig. 3.1 Change in income inequality in selected European countries (Reproduced from Tóth 2013)

levels and changes in Gini Index in understanding the link between income and segregation. In some countries, most notably in the UK and in Greece, levels of income inequality are high with very little change over the observed period. By contrast, levels of income inequality are low and with very little change in Norway and the Czech Republic. Other countries show different trajectories of change in income inequality, with some shifting from low inequality categories to the group of high inequality countries. The most notable examples occur across the formerly centrally planned countries of Eastern Europe.

Eastern European countries underwent political, social and economic transformations in the 1990s, and this brought about major changes in income distribution. Nevertheless, there were important differences between these countries. Across the former Soviet Baltic states of Estonia, Latvia and Lithuania, the Gini Index increased more than it did in the Visegrad countries, such as Hungary and the Czech Republic, which are included in this study. The very modest increase in income inequality was in the Czech Republic, which had the highest GDP per capita in the East before the political transformations, and the smallest decrease in GDP per capita in the 1990s (Tammaru et al. 2017) is especially notable. Interestingly, despite very complex reforms that included a transformation from central planning to a market economy within a democratic system, the Gini Index values initially increased moderately in Eastern Europe.

Under the influence of the newly introduced market system in Eastern Europe, the ideological value of blue-collar workers jobs and compressed wage structures under central planning was replaced by increased poverty and by increased returns to education in the 1990s (Brainerd 1998; Ladanyi and Szelenyi 2000; Stephens et al. 2015). Blue-collar workers lost their previous high social status, while young people 
born in the 1960s, and entering the labour market were among those who gained the most from the transitions, alongside members of the old elite (Helemäe et al. 2000; Węcławowicz 1998). Those who occupied better quality housing under central planning systems received the immediate rewards of housing privatisation that took place in the 1990s (Stephens et al. 2015). With time, these initial structures of housing inequality changes as those who benefitted more from economic restructuring and new opportunities on the labour market started to shape also the dynamics of the housing market, leading also to new forms of residential segregation (Kovács 2020; Tammaru et al. 2016; van Ham et al. 2018).

To conclude, three important messages arise from the analysis of the changes in income inequality in Europe since 1990s: (a) there has been a growth in income inequality; (b) the increase was especially rapid during the 1990s and (c) the formerly clear differences between the East and West became increasingly blurred. In this context, we are especially interested in how the levels of income inequality and changes in inequality correspond to levels and changes in socioeconomic residential segregation. Following the recent study by Tammaru et al. (2020), our guiding hypothesis for the analysis is as follows: we expect to find that levels of residential segregation correspond with levels of income inequality 10 years earlier. Since we have to rely on census data, we use a 10-year time lag in our analysis.

\subsubsection{Levels and Changes in Residential Segregation}

We start our analysis of residential segregation by plotting the values of the Dissimilarity Index between the top and bottom socioeconomic groups in 2001 and 2011 or at the time of the two last censuses in Fig. 3.2. To put the values in perspective, Marcińczak et al. (2015) suggest that the values of the Dissimilarity Index between socioeconomic groups can be interpreted as follows: values that are smaller than 20 can be interpreted as being low, and values that are 40 and higher can be considered being high. In this perspective, our first finding is that all the cities studied were characterised by medium levels of segregation in 2000. The only exception is Milan with a Dissimilarity Index above 40. The other most segregated cities in 2000 were London and Amsterdam. Our second finding relates to the geography of segregation in European cities in 2000 that corresponds to the level of income inequality in 1990. Eastern and Northern European cities are the least segregated, and Southern and Western European cities are the most segregated. More specifically, in our panel of cities, Oslo and Riga are the least segregated, and Amsterdam, Madrid and London are the most segregated.

Our third finding is that levels of segregation between top and bottom socioeconomic groups grew between the 2000 and 2011 census rounds, with Amsterdam as the only exception. As a consequence, the Dissimilarity Index reached the value of 40 and higher in five cities, Stockholm, London, Milan, Tallinn and Madrid, all belonging to different European macro-regions. In other words, while Milan and London already had high levels of segregation in 2000 and, hence changes in the 


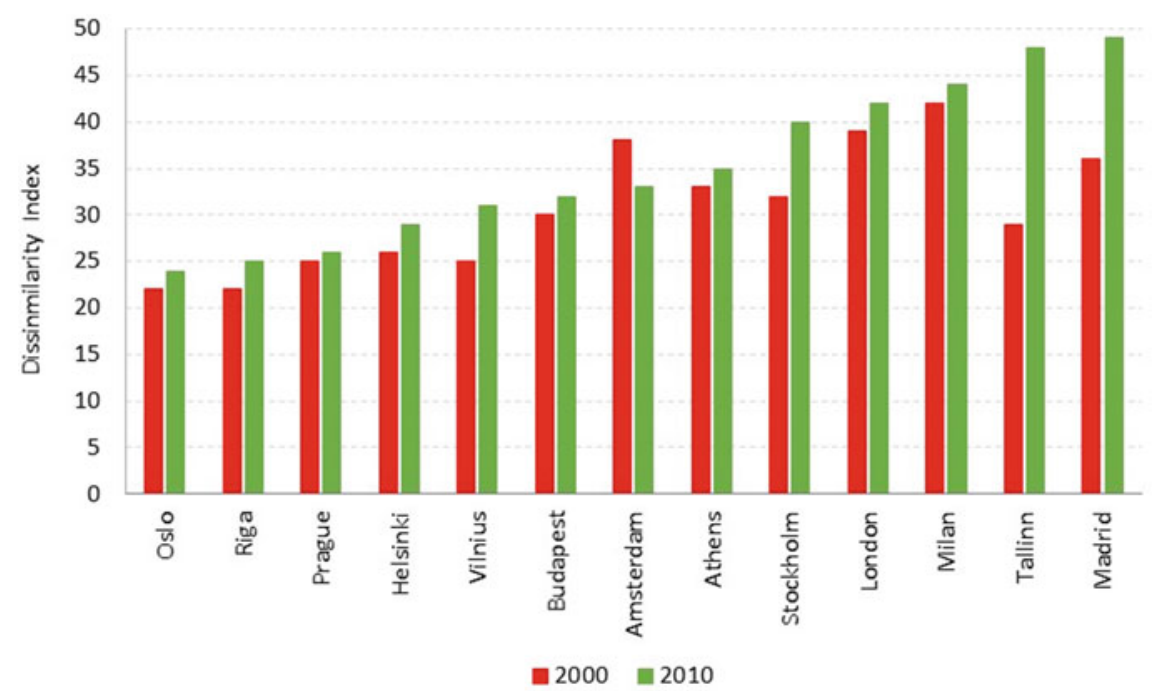

Fig. 3.2 Levels of residential segregation between the top and bottom socioeconomic groups in the panel of European cities, 2000 and 2010 (Tammaru et al. 2016a, b)

level of segregation between 2001 and 2011 were small, the rise of segregation was especially high in Stockholm, Tallinn and Madrid. Although different, the three cities with the most rapid increase in residential segregation in the 2000s shared a strong new housing construction boom in the 2000s before the housing sector collapsed in the 2008/2009 recession. New housing construction for the affluent tends to elevate levels of segregation. There are other more city-specific factors contributing to rising levels of segregation. Both in Stockholm and Tallinn, big and compact clusters of modernist blocks of high-rise housing can be found. As higher income groups move into newer and/or better housing, low-income groups are constrained to the areas where housing is most affordable. Immigrants and ethnic minorities are overrepresented in Stockholm and Tallin respectively. The arrival of large numbers of immigrants and refugees earning lower incomes has led to the strong overlap between ethnic and social segregation (Andersson and Kährik 2016).

The question, of why expectedly similar cities-e.g. the Baltic cities of Riga, Tallinn and Vilnius or the Nordic cities of Helsinki, Oslo and Stockholm-have shown different trajectories of change, is intriguing. Tallinn shows much higher levels of segregation in 2010 than Riga, yet these cities are very similar when it comes to history, economic structure, patterns of urban development and population composition (Krišjāne et al. 2016; Valatka et al. 2016). Both Tallinn and Riga belonged to the Soviet Union, underwent radical political, economic and social transformations in the 1990s that culminated in European Union membership in 2004, and both have sizeable Russian-speaking minority populations. Tammaru (Tammaru et al. 2017) explains the differences in the speed of economic recovery from the economic crises of the 1990s. Recovery was far more rapid in Tallinn compared to both Riga and 
Vilnius. There was also a strong overlap between ethnic and income inequality in Estonia. One effect of more rapid economic recovery was a private house building boom in Tallinn where homeownership increases alongside weak housing policy and high levels of income inequality, new housing construction tends to quickly elevate levels of segregation. In a market dominated context, new housing is accessible only for higher-earning households.

Differences in the growth of segregation levels between Nordic cities also warrant some attention. Oslo is the least segregated city with very modest growth in levels of segregation despite the fact that its housing sector has been market-dominated for decades. In Norway, the growth in income inequality has been low and the effects on segregation have been small and with a significant time lag. The oil-rich country has abundant resources for effective income redistribution policies (Wessel 2016). Helsinki and Stockholm are interesting comparison cities with moderate segregation levels in Helsinki and with only a small increase over time. Segregation in Stockholm is much higher after a strong increase between 2000 and 2010. The two cities differ from each other in important ways. First, Stockholm is bigger and more globally connected than Helsinki. Previous research shows that there are higher levels of segregation as a result of globalisation (Musterd et al. 2017). Second, and partly related to the first factor, Stockholm has been longer exposed to immigration. There is a growing overlap between social, ethnic and residential patterns in Stockholm, with low income and minority households over-represented in large housing estates that provide the most affordable housing (Andersson and Bråmå 2018).

Third, market principles have been introduced to Stockholm's housing market at a much quicker pace compared to Helsinki that still pursues active housing mix policies (Andersson and Kährik 2016; Dhalmann and Vilkama 2009; Eskelä 2018).

Amsterdam is also an interesting case, as this is the only city that experienced a drop in segregation levels. According to Musterd and van Gent (2016), the underlying mechanisms affecting residential sorting are very similar in Amsterdam to all other cities studied. The two main trends within residential mobility in the city are the gentrification of high-income households and suburbanisation of low-income households (Hochstenbach and Musterd 2018). The opposite direction of the change in income inequality and residential segregation has been explained by the segregation paradox; when the residential preferences of high-income households shift towards previously low-income neighbourhoods - as is characteristic of the gentrification process - a temporary mixing of income groups will follow (van Ham et al. 2020). This may reduce rather than increase the level of segregation, resulting in neighbourhoods where people with different incomes live together. However, over time, levels of segregation may start to rise and lower-income households begin to move from gentrifying neighbourhoods as house prices rise and wealthier people move in (Musterd and van Gent 2016).

In our earlier study, we found only a weak correlation between levels of income inequality and levels of residential segregation (Musterd et al. 2017; Tammaru et al. $2016 \mathrm{a}, \mathrm{b})$. In this paper, we introduce a time-lag between the two processes by contrasting graphically levels of the Dissimilarity Index with levels of the Gini Index 10 years earlier. A previous analysis by Tammaru (Tammaru et al. 2020) across 

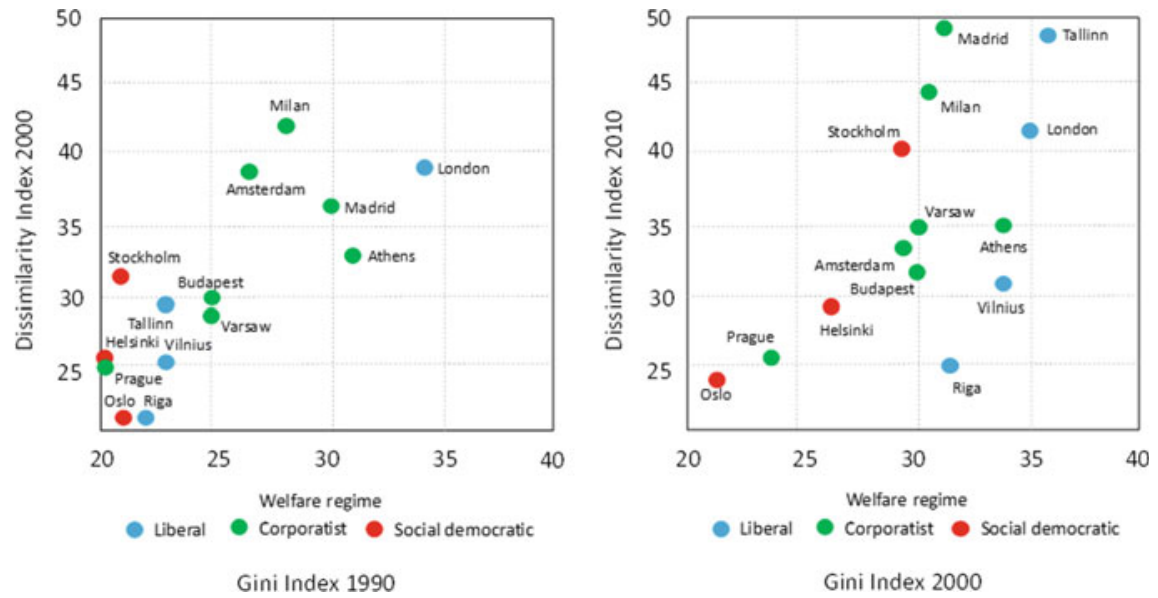

Fig. 3.3 Relationship between levels of income inequality (lagged 10 years) and residential segregation in European cities

Northern and Southern European countries showed that by lagging the two variables, their correlation becomes much stronger. Both the increase and decrease in income inequality relate to the increase and decrease in residential segregation 10 years later. The same holds true across our sample of 13 European cities at the two time-points used in our data analysis.

A positive correlation emerges from contrasting the Gini Index in 1990 with the Dissimilarity Index in 2000 (Fig. 3.3). In Prague, Oslo and Riga, income inequality was low in 1990 and residential segregation was low in 2000. In fact, Eastern European cities, shortly after the fall of the Berlin Wall in 1989, did not show any correlation between inequality and segregation. This holds equally for Baltic cities that later were labelled 'liberal', as it does for cities which at that time were still firmly social-democratic. In London, income inequality was highest in 1990 and residential segregation was highest in 2000. Other cities fall in-between. Stockholm deviates the most from this pattern. Levels of segregation in 2000 were somewhat higher than levels of income inequality would predict in 1990. Clearer positive correlations emerge when we contrast the Gini Index in 2000 with the Dissimilarity Index in 2010.

The spread in the upper end of the graph has increased somewhat, but when we consider the relation between lagged inequality and segregation for each of the three welfare regime types separately, we see three positive relations. The so-called liberal cities that reached relatively high levels of income inequality in 2000 show only moderately higher increases of levels of segregation-yet these are still increasing. Riga shows the most significant deviation where the level of residential segregation in 2010 is much lower than the 2000 level of income inequality would predict. Riga is an interesting case in this regard as in the 2000s, after joining the European Union, it has witnessed the highest level of emigration in our selection of cities. Migration 
in and out of a city, especially when on a massive scale, may intervene with the process of residential segregation (Bailey et al. 2017) At the other extreme, levels of residential segregation are higher in Madrid than one would predict from the level of income inequality in 2000. One of the reasons for this may relate to the extreme housing boom in Spain in the 2000s, partly supported by tourism and second-home buyers from across the world, which could distort the relationship.

\subsection{Conclusions and Future Research Avenues}

In this chapter, we reviewed the relationship between income inequality and socioeconomic segregation. We find that, in general, changes in segregation levels follow changes in inequality with a time lag. Change in levels of inequality leads to a change in levels of segregation 10 years later. Low levels of income inequality relate to low levels of segregation after 10 years, and high levels of inequality relate to high levels of segregation after 10 years. However, these findings need further research to address a number of limitations in our analysis.

First, our data do not allow for a more nuanced analysis of the length of the time lag. We use a 10-year time interval since this is determined by census interval and our ability to use only two census years. For example, the study by Wessel (2016) that used a longer time horizon for Oslo shows that the time needed for changes in inequality to changes in segregation maybe even longer, perhaps two decades or more. It may also be that changes evolve quickly in some cities. This happened in Tallinn at a time of rapid transformation from a centrally planned society to a market-based one (Tammaru et al. 2016a, b).

Second, comparative analysis over time and space always raises concerns regarding data comparability. The Gini Index may be calculated in different ways that yield very different outcomes, due to differences in how the tax redistribution is considered, for example (Hellebrandt and Mauro 2015). Moreover, the calculation of Dissimilarity Index is sensitive to the spatial units used. Therefore, further comparative studies are needed that focus on segregation at different spatial scales and spatial configurations and how it varies from city-to-city. Furthermore, the Dissimilarity Index is spatially blind and, hence, may hide more than it reveals. For example, stability of the Dissimilarity Index over decades may mask dramatic changes in the geography of segregation as low- and high-income group sort over houses and neighbourhoods (van Ham et al. 2020). In the course of residential sorting, as a result of gentrification of inner-city neighbourhoods, for example, various forms of mixing and separation may occur at different spatial scales, with the outcome that city-wide measures of segregation such as Dissimilarity Index hardly change.

Third, the finding that a change in inequality leads to a change in segregation is not necessarily causal. It may be that other factors drive levels of segregation that are correlated with inequality. Most importantly, in Europe, immigration is an important intervening factor. Immigrants are more likely to work in lower-income occupations. Hence, the arrival of large numbers of migrants may increase both income inequality 
and residential segregation. Large, economically dynamic urban areas are particularly likely to attract migrants, leading to both increased inequality and increased segregation (Glaeser 2008). Other mechanisms may be related to inequality and segregation in a co-evolutionary way. Segregation exacerbates inequality via spatial opportunity structures (Galster and Sharkey 2017) and through the importance of housing in the overall degree of social stratification (Tammaru et al. 2017). For example, living in certain neighbourhoods affects opportunities to find a job and as well as access to school for children. As a result, the neighbourhood of residence is not only affected by inequality but is also an inherent part of inequality in modern urban societies, with residential advantage and disadvantage being passed from parents to children.

To conclude, our study found a strong correlation between residential socioeconomic segregation and levels of income inequality observed 10 years earlier. Future studies are needed to shed light on the causal and co-evolutionary characteristics of this relationship, and the inter-generational connection between inequality and segregation.

Acknowledgements We would like to gratefully acknowledge the important contributions of all the co-authors of the book 'Socioeconomic Segregation in European Capital Cities: East Meets West', David Manley, Ron Johnston, Kelvyn Jones, Dewi Owen, Wouter van Gent, Gerhard Hatz, Josef Kohlbacher, Ursula Reeger, Roger Andersson, Anneli Kährik, Terje Wessel, Thomas Maloutas, Petros Petsimeris, Dtefania Rimlodi, Jesús Leal, Daniel Sorando, Zoltán Kovács, Balázs Szabó, Martin Ouředníček, LucieLucie Pospíšilová, Petra Špačková, Zuzana Kopecká, Jakub Novák, Zaiga Krišjāne, Māris Bērziņš, Kalju Kratovtiš, Vytautas Valatka, Donatas Burneika, Rūta Ubarevičienè, Kadi Mägi and Kadri Leetmaa. Research leading to these results has received funding from the Estonian Research Council (PUT PRG306, Infotechnological Mobility Laboratory, RITA-Ränne), from TU Delft (visiting professorship of Tiit Tammaru), from the European Commission Horizon 2020 project UPLIFT, from Research Council under the European Union's Seventh Framework Program (FP/2007-2013), and from European Research Council Grant Agreement number 615159 (European Research Council Consolidator Grant DEPRIVEDHOODS, Socio-spatial inequality, deprived neighbourhoods, and neighbourhood effects).

\section{References}

Andersson R, Bråmå ̊̊ (2018) The Stockholm estates—a tale of the importance of initial conditions, macroeconomic dependencies, tenure and immigration: Springer, Cham

Andersson R, Kährik A (2016) Widening gaps: Segregation dynamics during two decades of economic and institutional change in Stockholm. In: Tammaru T, van Ham M, Marcińczak S, Musterd S (eds) Socio-economic segregation in European capital cities: East meets West: London. Routledge, New York, pp 110-131

Arundel R (2017) Equity inequity: Housing wealth inequality, inter and intra-generational divergences, and the rise of private landlordism. Housing, Theory and Society 34(2):176-200

Autor DH, Levy F, Murnane RJ (2001) The skill content of recent technological change: An empirical exploration: Citeseer

Bailey N, van Gent WP, Musterd S (2017) Remaking urban segregation: processes of income sorting and neighbourhood change. Population, Space and Place 23(3):e2013 
Boterman W, Musterd S, Pacchi C, Ranci C (2019) School segregation in contemporary cities: Socio-spatial dynamics, institutional context and urban outcomes. Urban Studies 56(15):30553073

Brainerd E (1998) Winners and losers in Russia's economic transition. American Economic Review, $1094-1116$.

Cirillo V (2017) Technology, employment and skills. Economics of Innovation and New Technology 26(8):734-754

Cutler DM, Glaeser EL (1997) Are ghettos good or bad? Q J Econ 112(3):827-872

Dhalmann H, Vilkama K (2009) Housing policy and the ethnic mix in Helsinki, Finland: perceptions of city officials and Somali immigrants. J Housing Built Environ 24(4):423

Eskelä E (2018) Housing pathways of skilled migrants: Indian professionals in Helsinki, Finland. Housing, Theory and Society 35(4):474-494

Fujita K, Maloutas T (2016) Residential Segregation in Comparative Perspective: Making Sense of Contextual Diversity. Routledge, London

Galster G, Andersson R, Musterd S (2015) Are males' incomes influenced by the income mix of their male neighbors? Explorations into nonlinear and threshold effects in Stockholm. Housing Studies 30(2):315-343

Galster, G., \& Sharkey, P. (2017). Spatial foundations of inequality: A conceptual model and empirical overview. RSF: The Russell Sage Foundation Journal of the Social Sciences, 3(2), $1-33$

Glaeser EL (2008) Cities, agglomeration, and spatial equilibrium. Oxford University Press

Hamnett C (1994) Socio-Economic Change in London: Professionalization not Polarization. Built Environment 20(3):192-203

Hamnett, C. (2020). The changing social structure of global cities: Professionalisation, proletarianisation or polarisation. Urban Studies, 0042098020940556.

Hedman, L., \& van Ham, M. (2021). Three Generations of Intergenerational Transmission of Neighbourhood Context. Social Inclusions.

Helemäe, J., Saar, E., \& Vöörmann, R. (2000). Kas haridusse tasus investeerida? Hariduse selekteerivast ja stratifitseerivast rollist kahe põlvkonna kogemuse alusel [Returns to Education. The selective and Stratifying Effect of Education in Two Generations] Teaduste Akadeemia Kirjastus. Tallinn.

Hellebrandt, T., \& Mauro, P. (2015). The future of worldwide income distribution. Peterson Institute for international economics working paper (15-7).

Hochstenbach C, Boterman WR (2017) Intergenerational support shaping residential trajectories: Young people leaving home in a gentrifying city. Urban Studies 54(2):399-420

Hochstenbach C, Musterd S (2018) Gentrification and the suburbanization of poverty: Changing urban geographies through boom and bust periods. Urban Geography 39(1):26-53

Hulchansky D (2010) The three cities in Toronto: Income polarization among Toronto's neighbourhoods, 1970-2005. University of Toronto, Toronto

Johnston R, Propper C, Sarker R, Jones K, Bolster A, Burgess S (2005) Neighbourhood social capital and neighbourhood effects. Environment and Planning A 37(8):1443-1459

Kain JF (1968) Housing segregation, negro employment, and metropolitan decentralization. Q J Econ 82(2):175-197

Kornai, J. (1992). The socialist system: The political economy of communism: Oxford University Press.

Kovács, Z. (2020). Do market forces reduce segregation? The controversies of post-socialist urban regions of Central and Eastern Europe. In S. Musterd (Ed.) Handbook of Urban Segregation: Chichester: Edward Elgar Publishing, 118-132.

Krišjāne Z, Bērzinsš M, Kratovitš K (2016) Occupation and ethnicity: Patterns of residential segregation in Riga two decades after socialism. In: Tammaru T, van Ham M, Marcińczak S, Musterd S (eds) Socio-economic segregation in European capital cities: East meets West: London. Routledge, New York, pp 287-312 
Krueger, A. B. (2012). The rise and consequences of inequality in the United States. Speech at the Center for American Progress, 12.

Ladanyi J, Szelenyi I (2000) Poverty and social structure in transitional societies. Yale University, Centre for Cooperative reseach

Marcińczak S, Tammaru T, Novák J, Gentile M, Kovács Z, Temelová J, Szabo B (2015) Patterns of socioeconomic segregation in the capital cities of fast-track reforming postsocialist countries. Ann Assoc Am Geogr 105(1):183-202

Marcińczak S, Musterd S, van Ham M, Tammaru T (2016) Inequality and rising levels of socioeconomic segregation: Lessons from a pan-European comparative study. In: Tammaru T, van Ham M, Marcińczak S, Musterd S (eds) Socio-economic segregation in European capital cities: East meets West: London. Routledge, New York, pp 358-382

Musterd, S. (2020) (Ed.) Handbook of Urban Segregation: Chichester: Edward Elgar Publishing.

Musterd, S., Marcińczak, S., van Ham, M., \& Tammaru, T. (2017). Socioeconomic segregation in Euopean capital cities. Increasing separation between poor and rich. Urban Geography, 38(7), 1062-1083.

Musterd S, van Gent W (2016) Changing welfare context and income segregation in Amsterdam and its metropolitan area. In: Tammaru T, van Ham M, Marcińczak S, Musterd S (eds) Socioeconomic segregation in European capital cities: East meets West: London. Routledge, New York, pp 55-79

Nieuwenhuis J, Tammaru T, van Ham M, Hedman L, Manley D (2020) Does segregation reduce socio-spatial mobility? Evidence from four European countries with different inequality and segregation contexts. Urban Studies 57(1):176-197

Nightingale CH (2012) Segregation: A global history of divided cities. University of Chicago Press, Chicago

Owens A, Candipan J (2019) Social and spatial inequalities of educational opportunity: A portrait of schools serving high-and low-income neighbourhoods in US metropolitan areas. Urban Studies 56(15):3178-3197

Sassen S (1991) The global city. Princeton University Press, Princeton

Scarpa S (2016) Looking beyond the neighbourhood: income inequality and residential segregation in Swedish metropolitan areas, 1991-2010. Urban Geography 37(7):963-984

Stephens M, Lux M, Sunega P (2015) Post-socialist housing systems in Europe: Housing welfare regimes by default? Housing Studies 30(8):1210-1234

Szelenyi, I. (1996). Cities under Socialism - and After. In Andrusz, G., Harloe, M. \& Szelenyi, I. (Eds.), Cities After Socialism: Urban and Regional Change and Conflict in Post-Socialist Societies New York: Wiley.

Tammaru T, Marcińczak S, Aunap R, van Ham M, Janssen H (2020) Relationship between income inequality and residential segregation of socioeconomic groups. Regional Studies 54(4):450-461

Tammaru, T., Marcińczak, S., \& Kukk, K. (2017). Social transformations, housing and socioeconomic segregation in the fast-track reform countries The Routledge International Handbook of European Social Transformations (pp. 159-171): Routledge.

Tammaru T, Marcińczak S, van Ham M, Musterd S (eds) (2016a) Socio-Economic Segregation in European Capital Cities: East Meets West (Regions and Cities). Routledge, London and New York

Tammaru T, Musterd S, van Ham M, Marcińczak S (2016b) A multi-factor approach to understanding socio-economic segregation in European. In: Tammaru T, van Ham M, Marcińczak S, Musterd S (eds) Socio-economic segregation in European capital cities: East meets West: London. Routledge, New York, pp 1-29

Tóth, I. (2013). GINI Policy Paper 3: Time series and cross country variation of income inequalities in Europe on the medium run: are inequality structures converging in the past three decades? : AIAS, Amsterdam Institute for Advanced Labour Studies.

Valatka V, Burneika D, Ubarevičienè R (2016) 13 Large social inequalities and low levels of socioeconomic segregation in Vilnius. In: Tammaru T, van Ham M, Marcińczak S, Musterd S (eds) 
Socio-economic segregation in European capital cities: East meets West: London. Routledge, New York, pp 313-332

van Ham, M., Tammaru, T., \& Janssen, H. J. (2018). A multi-level model of vicious circles of socio-economic segregation. Divided cities: understanding intra-urban disparities. OECD, Paris.

van Ham, M., Uesugi, M., Tammaru, T., Manley, D., \& Janssen, H. (2020). Changing occupational structures and residential segregation in New York, London and Tokyo. Nature Human Behaviour, $1-11$.

Vihalemm P, Masso A, Opermann S (2017) The Routledge international handbook of European social transformations. Routledge, London

Węcławowicz, G. (1998). Social polarization in postsocialist cities: Budapest, Prague and Warsaw. In G. Enyedi (Ed.), Social Change and Urban Restructuring in Central Europe Budapest: Akadémiai Kiadó.

Wessel T (2016) Economic segregation in Oslo: polarisation as a contingent outcome. In: Tammaru T, Marcińczak S, van Ham M, Musterd S (eds) Socio-Economic Segregation in European Capital Cities: East Meets West. Routledge, London and New York, pp 156-179

Wilson WJ (1987) The Truly Disadvantaged: The Inner City, The Underclass, and Public Policy. University of Chicago Press, Chicago

Open Access This chapter is licensed under the terms of the Creative Commons Attribution 4.0 International License (http://creativecommons.org/licenses/by/4.0/), which permits use, sharing, adaptation, distribution and reproduction in any medium or format, as long as you give appropriate credit to the original author(s) and the source, provide a link to the Creative Commons license and indicate if changes were made.

The images or other third party material in this chapter are included in the chapter's Creative Commons license, unless indicated otherwise in a credit line to the material. If material is not included in the chapter's Creative Commons license and your intended use is not permitted by statutory regulation or exceeds the permitted use, you will need to obtain permission directly from the copyright holder.

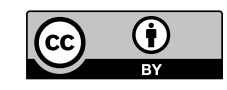

